\title{
Entrevista com Pedro Antônio Giraldi ${ }^{1}$
}

\author{
Entrevistadora: \\ Lísia Regina Ferreira Michels ${ }^{2}$
}

\section{Michels - Prof. Pedro, como foi sua formação profissional?}

Giraldi - Iniciei minha formação profissional cursando Pedagogia, porque me interessei desde muito cedo pela Educação, por incrível que pareça, com movimentos religiosos nas comunidade de base, onde sob as coordenações de um Padre e Diáconos realizamos de 1965 a 1973 um trabalho de reflexão sobre textos da bíblia que considerávamos importantes, não só do ponto de vista espiritual mas para formação pessoal e, é claro, aproveitávamos também desses momentos para discutirmos questões relacionadas à educação em geral e a organização dessas comunidades, considerando que o país vivia uma ditadura militar onde a repressão era evidente em quase todos os setores da sociedade. Esses movimentos foram se tomando tão intensos, e segundo alguns, poderiam comprometer a segurança social e então fomos impedidos de continuar. Foi um período muito marcante tanto para minha vida pessoal quanto para o direcionamento profissional. Pude perceber na prática a influência que o professor exerce na sociedade e como uma população bem orientada é capaz de organizar-se com mas iniciativa e criatividade. Cursando Pedagogia em 1975, uma disciplina chamou-me atenção pela segunda vez na minha vida de forma marcante que foi Psicologia da Educação. Então, decidi interromper o curso de Pedagogia para cursar Psicologia.

Fiz o mestrado em Neurociência. Escolhi este tema para pós-graduação porque entendo que uma melhor compreensão do mundo psicológico passa pelas causas neurológicas.

\section{Michels - Como foi o início de seu trabalho em Psicologia?}

Giraldi - Cursei Psicologia na Faculdade Salesiana de Filosofia Ciências e Letras de Lorena, em São Paulo, de 1976 a 1980. Durante o último ano de Faculdade (formação para psicólogo), fiz um curso de Especialização em Psicomotricidade.

Retomei para a minha cidade natal Itajaí-SC no final de 1980 e em 1981, iniciei meu trabalho em Psicologia lecionando Psicologia da Educação para um curso de Magistério (antigo $2^{\circ}$ grau, atual ensino médio) e trabalhei com terapia psicomotora numa clínica multiprofissional.

Posteriormente, fui contratado como psicólogo do Colégio de Aplicação da Fepevi (atual Univali) e também como professor de Psicologia da Educação para os cursos de Pedagogia e Estudos Sociais.

\section{Michels - O que o levou a atuar em Psicologia Escolar?}

Giraldi - Como segundo psicólogo a residir na cidade no início da década de 1980, percebi uma grande receptividade pela psicologia das pessoas que administravam as instituições, tanto no ramo da educação, quanto assistencial. Fui o primeiro psicólogo contratado por um colégio particular na cidade e o primeiro a lecionar Psicologia, pois as disciplinas de Psicologia tanto do ensino médio

\footnotetext{
${ }^{1}$ Mestre em Neurociências - Universidade de Sevilha - Espanha, Docente do Curso de Psicologia da Universidade do Vale do Itajaí - UNIVALI, Itajaí-SC. E-mail: girardi@matrix.iai.com.br

${ }^{2}$ Mestre em Psicologia Social e da Personalidade - Pontifícia Universidade Católica do Rio Grande do SulPUCRS. Coordenadora e Docente do Curso de Psicologia da Universidade do Vale do Itajaí - UNIVALI. Email: lrm@melim.com.br
} 
quanto na educação superior eram lecionadas por profissionais formados em outros cursos.

No ano de 1986, após as reuniões dos Conselhos da Univali, ficou estabelecido que em agosto de 1987 deveria iniciar a primeira turma do curso de Psicologia. Neste ano de 1986, meu nome foi indicado pelo reitor para participar de uma comissão juntamente com mais dois professores, da implantação da Faculdade de Psicologia que foi concretizada no ano seguinte, onde fui nomeado como primeiro diretor, permanecendo no cargo até o final do $8^{\circ}$ período da primeira turma do curso. Após deixar a direção, tomei-me professor do curso onde lecionei as disciplinas Teorias e Sistemas em Psicologia, Psicomotricidade. Como já possuía prática na área da Psicologia Escolar por ter trabalhado nesta área, além do Colégio de Aplicação da Univali, também em outro importante colégio da cidade, fui convidado para fazer parte do quadro dos supervisores em Psicologia Escolar. Portanto, a minha atuação na Psicologia Escolar foi resultado de um amadurecimento profissional através de vários trabalhos práticos realizados nas escolas como professor e psicólogo, e nas diversas instituições educacionais em que trabalhei.

\section{Michels - Como foi e está sendo sua trajetória na Psicologia Escolar?}

Giraldi - Quando iniciei meu trabalho como psicólogo escolar no colégio da Universidade, percebi o quanto foi importante a presença do psicólogo na instituição, a procura dos pais, alunos e professores solicitando orientações quanto ao comportamento dos filhos, dificuldades de aprendizagem, de escolha de um curso para fazer o vestibular, de integração entre professores e entre alunos... demonstrando assim, o quanto um psicólogo escolar precisa estar bem preparado e também o quanto este profissional é, sem dúvida nenhuma, indispensável na escola.

Quero salientar que na ocasião em que trabalhei como psicólogo nesta escola, havia uma equipe que eu considerava e considero ainda hoje ideal para uma escola. Nossa equipe técnica era constituída pelo diretor do Colégio, orientador pedagógico, educacional, disciplinar e por um psicólogo escolar. Cada qual com suas tarefas definidas. Nessa equipe as questões eram discutidas através de reuniões com a direção da escola.

A minha experiência em Psicologia Escolar propriamente dita, como supervisor é ainda recente, porque o curso de Psicologia está completando seu $13^{\circ}$ ano de implantação e os estágios supervisionados iniciaram há nove anos, posso afirmar que essa experiência é sem dúvida das mais desafiadoras e das mais gratificantes. Desafiadora por que 95\% dos colégios onde os estagiários estão realizando as práticas, não possuem em seus quadros técnicos o psicólogo escolar. Isso dificulta muito o trabalho dos supervisores que têm estagiários nas instituições escolares e que muitas vezes passam a ser vistos como profissionais dispensáveis para a instituição. É gratificante porque percebe-se que a cada escola em que se trabalha observa-se mudanças da mentalidade quanto à importância do papel do profissional de Psicologia na instituição escolar.

\section{Michels - Como imagina o futuro da Psicologia Escolar?}

Giraldi - Embora seja difícil fazer qualquer previsão na atualidade, vou arriscar algumas. Primeiramente, quanto à ocupação do espaço profissional. O psicólogo escolar, aos poucos, vai desenvolvendo um trabalho importantíssimo nas instituições escolares e com ele a Psicologia Escolar vai ocupando espaço e o trabalho que era feito por outros profissionais. Muitas escolas privadas já possuem os serviços de Psicologia Escolar e acredito que num curto espaço de tempo não haverá nenhuma dessas escolas que não possuam esses serviços. Ainda falta sensibilidade por 
parte dos poderes públicos de alguns estados e municípios, para contemplarem nos concursos públicos a função do psicólogo escolar como obrigatoriedade de contratação, de pelo menos um psicólogo escolar para cada escola. Quanto à Psicologia Escolar, acredito que ela avançou muito pouco no sentido de sua eficiência para trabalhar as relações escolares. A Psicologia Escolar precisa ser mais prática, mais objetiva. O psicólogo escolar ainda é um profissional que limita muito o seu campo de atuação na escola. A Psicologia Escolar precisa também ser mais preventiva. Muitas escolas entendem a Psicologia Escolar como meio para resolver somente as dificuldades escolares dos alunos e não as dificuldades de quem administra e de quem ministra as aulas. Nesse sentido, a Psicologia Escolar não consegue avançar e passa unicamente a administrar problemas, quando além desses, deveria atuar na direção do desenvolvimento e crescimento pessoal de todos que fazem parte da instituição escolar. A escola é um campo de trabalho e de pesquisas importantíssimo para o psicólogo escolar, no entanto, observa-se que ainda há pouco interesse por grande parte dos profissionais quanto esse tipo de opção. Observo uma grande receptividade das escolas quanto aos serviços que este importante ramo da psicologia oferece, no entanto, as oportunidades para discussão desses serviços ainda são muito limitadas. Faz-se necessário a realização de encontros estaduais ou regionais para discutir-se melhor a realidade da Psicologia Escolar, para saber-se como e para onde caminham as intervenções. 